\title{
Geneses of labour market turnover: Job search and entrepreneurial aspirations on-the-job
}

\author{
Ari Hyytinen \\ Research Institute of the Finnish Economy (ETLA) \\ and \\ Pekka Ilmakunnas \\ Helsinki School of Economics and HECER
}

Discussion Paper No. 33

November 2004

ISSN 1795-0562

HECER - Helsinki Center of Economic Research, P.O. Box 17 (Arkadiankatu 7), FI-00014 University of Helsinki, FINLAND, Tel +358-9-191-28780, Fax +358-9-191-28781, E-mail info-hecer@helsinki.fi, Internet www.hecer.fi 


\title{
Geneses of labour market turnover: Job search and entrepreneurial aspirations on-the-job*
}

\begin{abstract}
In this paper we study the labour market behavior of employed individuals that have entrepreneurial aspirations in addition to aspirations to switch job. We analyze empirically these two "search processes" side-by-side and report three main findings: First, neither entrepreneurial aspirations nor aspirations to switch job are uncommon, but only few are engaged in both search processes. Second, the two processes are not alike: It is more difficult to empirically explain entrepreneurial aspirations than aspirations to switch job. Only few observable characteristics of the employed are related to both processes. Varied experience and job dissatisfaction are directly related to the probability of having entrepreneurial aspirations and aspirations to switch job, while job tenure is inversely related to them. Finally, the two processes are not conditionally independent. Unobservable heterogeneity common to many non-searchers drives this result.
\end{abstract}

JEL Classification: J230, J640, L200

Keywords: entrepreneurship, job search, experience, job satisfaction

Ari Hyytinen

Research Institute of the Finnish

Economy (ETLA)

Lönnrotinkatu 4B

FI-00120 Helsinki School of Economics

FINLAND

e-mail: ari.hyytinen@etla.fi
Pekka Ilmakunnas

Department of Economics

Helsinki School of Economics

P.O. Box 1210

FI-00101 Helsinki

FINLAND

e-mail: Pekka.ilmakunnas@hkkk.fi

* Comments from Edvard Johansson, Antti Kauhanen, Petri Rouvinen and seminar participants at EALE 2004 and EARIE 2004 conferences have helped to improve the paper. Hyytinen gratefully acknowledges the financial support provided by the National Technology Agency of Finland (Tekes, project 579/31/03) and IImakunnas support by Academy of Finland (project 50950). An earlier version of this paper appeared as "Entrepreneurial aspirations", ETLA discussion paper No. 890. 
Job-to-job switches account for a large part of labour market turnover (see e.g. Farber, 1999). It is therefore unsurprising that on-the-job search for labour market opportunities is a widely recognized and studied phenomenon. In this paper, we explore the previously overlooked possibility that employed individuals may have entrepreneurial aspirations in addition to aspirations to switch job. ${ }^{1}$

Having entrepreneurial aspirations reflects a type of search for entrepreneurial opportunities. From the theoretical point of view, such search is not dramatically different from on-the-job search for a new job. First, the basic structure of the two decision problems is the same: Individuals considering entrepreneurship or a new job select a strategy to maximize their own discounted lifetime income or utility, are forward-looking and transit into the new position on the basis of a rational selection process. For the employed, the comparison of the options involves, among other things, the wage lost, be the considered option an entrepreneurial opportunity or a new job offer. Second, there are search costs and randomly arriving opportunities in both cases. In the standard models of entrepreneurship, the search process is implicit, but were it explicitly modeled, it would be - not unlike in the job search models - about acquiring market information and analyzing randomly arriving opportunities.

It turns out that the available empirical literature on on-the-job search for a new job and entrepreneurship suggests that many if not most of the empirical determinants contributing to on-the-job search are deceptively similar to the determinants impacting the probability of becoming an entrepreneur. If indeed the basic structure of the two decision problems is similar and there are search costs and randomly arriving opportunities in both cases, this apparent similarity is not surprising. Descriptive accounts also seem to support the similarity of the two search or "scanning" processes (see, for example, Krueger et al., 2000).

The aim of this paper is to take a closer empirical look at the two search processes: Are entrepreneurial aspirations on-the-job common? Do the same persons simultaneously search for a new job and entrepreneurial opportunities? To

\footnotetext{
${ }^{1}$ On-the-job search alone has been investigated by Blau (1992), Pissarides and Wadsworth (1993), and Manning (2003), among others. Entrepreneurial intentions alone have been studied by Blanchflower, Oswald, and Stutzer (2001). In social psychology oriented management research, there also exists a strand of literature studying entrepreneurial intentions (see, e.g., Krueger et al., 2000).
} 
what extent do the determinants of these processes differ? Can observables explain them equally well? Are the two processes related after observable characteristics of the employed are controlled for? These are the questions we address. To the best of our knowledge, no other paper has previously modeled these phenomena side-by-side and compared their correlates.

Albeit our analysis focuses on modeling the two search processes side-byside, it also contributes, so we hope, to the recent literature that explores entrepreneurial origins and entrepreneurs' experiences prior to entrepreneurship. ${ }^{2}$ We believe, in particular, that there is a lot to learn from the data on entrepreneurial aspirations. First of all, the aspirations data allow us to investigate a population of potential entrepreneurs. Studying this population complements the previous analyses of actual entrepreneurship that typically use either crosssectional or longitudinal data: The former data cannot mirror any dynamics related with the self-employment choice, because they reflect the status quo that prevails at each point in time. A problem with the latter data is that actual transitions into entrepreneurship are relatively rare. Because having entrepreneurial aspirations is the logical step just prior to a transition, it is of interest to ask if the transitions are rare because entrepreneurial aspirations are rare. If that is not the case, something probably prevents the realization of the aspirations. If that is the case, the micro-economic determinants of potential entrepreneurship are of special interest, because it is then the potential supply of high-quality entrepreneurs "from-the-job" that is a binding constraint (unless, of course, entrepreneurial opportunities can be pursued instantly without search, which hardly is the case). ${ }^{3}$ Understanding the selection into entrepreneurship is of current policy relevance, because many policy-makers trust that entrepreneurship is a key driver of the world's most dynamic economies.

A potential criticism against using aspirations data is of course that an individual's aspirations may predict her actions poorly even if she is

\footnotetext{
${ }^{2}$ The emphasis in the academic economics research on entrepreneurial origins has often been either on cross-sectional determinants of self-employment choice or on job-to-entrepreneurship and unemployment-to-entrepreneurship switches in longitudinal data. See, e.g., Blanchflower and Oswald (1998), Le (1999), Blanchflower (2000), Dunn and Holtz-Eakin (2000), Audretsch (2003), and Parker (2004).

${ }^{3}$ In any event, wider use of aspirations data might be useful because some of the estimated effects in the previous literature seem to depend on whether cross-sectional and longitudinal data are used (for these differences, see Le, 1999).
} 
unconstrained to pursue them. We have three responses to this type of criticism. For our analysis to make sense it is required only that entrepreneurial aspirations are positively (but not perfectly) correlated with the actual transitions to entrepreneurship. If this correlation is weak, something of a paradox emerges. The source of the paradox is that unless the transitions to entrepreneurship are preceded by some kind of evolution and systematic development of entrepreneurial ideas (i.e., "on-the job search for them") that the entrepreneurial aspirations reflect, "true" potential entrepreneurship on-the-job is next to random or unpredictable. Finally, psychological studies suggest that intentions indeed predict (planned) behavior, particularly when that behavior is rare or hard to observe (see Krueger et al. 2000 and the references therein). The results from this literature suggest that models of intentions are useful in understanding and predicting entrepreneurial activity.

We examine entrepreneurial aspirations and aspirations to switch job using the Finnish Quality of Work Life Survey from the year 1997. We report three main findings. First, neither entrepreneurial aspirations nor job search are uncommon, but only few are engaged in both search processes. Second, despite their apparent similarity, the two processes are not alike: It is more difficult to empirically explain entrepreneurial aspirations than aspirations to switch job. It turns out that only varied experience and job tenure are associated both with entrepreneurial aspirations and aspirations to switch job: Varied experience and job dissatisfaction are directly related to the probability of having entrepreneurial aspirations and aspirations to switch job, while job tenure is inversely related to them. No other observable characteristic of the employed is related to both processes.

Third, even after controlling for a number of observable characteristics of the employed, the (conditional) independence of the two processes can be rejected at the $1 \%$ significance level. Unobservable heterogeneity common to many nonsearchers drives this result, as there are only few who are both potential entrepreneurs and job switchers.

The rest of the paper is organized as follows: In the next section we outline a theoretical framework for our empirical analysis. In section 3 we discuss the data and estimation issues. In section 4 we present the results of our empirical analysis. Section 5 contains a brief summary. 


\section{Theoretical preliminaries}

\subsection{Basic framework}

The theory of on-the-job search explains why some search for a new job on-thejob while others do not, with nonzero search costs providing a prominent explanation for the inactivity on-the-job (e.g. Burdett, 1978). On the other hand, the relative efficiencies of search as unemployed or on-the-job have an influence on how the search is conducted. The theory also predicts that for a given (nonzero) level of search costs, the distribution from which the job offers are drawn determines the search decision.

Absent a theory of entrepreneurial aspirations, the search for entrepreneurial opportunities on-the-job can be thought to be determined in the same way as the search for a better job is. As said, we believe that the two search processes are similarly determined, because the search for entrepreneurial opportunities parallels on-the-job search for a better job at least in two important ways. First, the basic structure of the two decision problems is the same: As suggested by the previous studies (see for example Evans and Jovanovic, 1989, and Holtz-Eakin, Joulfaian and Rosen, 1994), individuals considering entrepreneurship select a strategy to maximize their own discounted lifetime income or utility, are forwardlooking and transit into entrepreneurship on the basis of a rational selection process. For the employed, the comparison of the options involves the wage lost if an entrepreneurial opportunity is pursued. If the employed individuals (that are potential entrepreneurs) behave in this manner, the determinants of the decision to search for entrepreneurial opportunities are not too different from those of the standard decision to search for a new job.

Second, there are search costs and randomly arriving opportunities in both cases. In the standard models of entrepreneurship (Evans and Jovanovic, 1989, and Holtz-Eakin et al., 1994), the search process is implicit. Were it however explicitly formalized, it would be about acquiring market information and analyzing randomly arriving entrepreneurial opportunities (see also Krueger et al. 2000), just like in the job-search models. The randomly arriving opportunities, in turn, might be related for example to the uncertainty regarding the mean of the distribution determining an individual's gross earnings as an entrepreneur. The data on entrepreneurial aspirations on-the-job should thus systematically reflect 
similar rational considerations, economic laws and constraints as those that govern the data on job search on-the-job.

We next look for potential determinants of entrepreneurial aspirations and aspirations to switch job from the literature on entrepreneurship and on job search, respectively. We believe that the potential determinants reflect both search costs and the distribution of job offers/entrepreneurial opportunities, allowing us thus to develop a framework that we can use to guide our empirics.

\subsection{Determinants of entrepreneurial aspirations}

The literature on entrepreneurship has during recent years grown rapidly if not exploded. Nice roadmaps to this increasingly diversified literature are Le (1999), Blanchflower (2000), Audretsch (2003), and Parker (2004). There is, unfortunately, no unified theory of entrepreneurship. Instead, there are many theories, which vary a lot both in terms of their focus and generality.

Both cross-sectional studies and longitudinal data support the proposition that a large number of various economic, sociological, psychological, cultural and environmental factors impact the probability of becoming an entrepreneur. However, of these various factors some are economically (and empirically) more relevant than the others. On the basis of the recent literature, we consider the following factors: educational attainment (e.g., the level and field of education), occupational status (e.g., professional status and industry), individual and family background characteristics (e.g., gender, marital status, number of dependents), income from present occupation, and various characteristics of the economic environment (e.g., the area of residence). ${ }^{4}$

On and above the foregoing candidate determinants of entrepreneurial aspirations, we also include labour market experiences. We include them, because

\footnotetext{
${ }^{4}$ This is of course not a complete list. It does encompass, however, a non-negligible subset of the empirically most relevant determinants of entrepreneurship as identified in the received literature. Because our data are from Finland and about entrepreneurial aspirations of individuals currently on-the-job, we can to some extent limit the range of relevant variables: First, ethnic background and race that have been examined especially in the U.S. literature are not relevant in Finland because of the homogeneous population and small number of immigrants. Second, because our data refer to individuals currently on-the-job, certain specific determinants of unemployment-toentrepreneurship switches are not of primary interest to us. Finally, there are relatively few published empirical studies of the determinants of transitions from salaried employment to selfemployment that use Finnish data and that would suggest variables on and above the ones we consider here: Using data on test scores from a battery of ability and personality tests, Uusitalo
} 
for example years worked, number of similar jobs held, and job tenure have been identified to affect switches to entrepreneurship in the previous studies. ${ }^{5}$ It is a relatively well-documented fact that the rewards from entrepreneurship are so low that entrepreneurship can hardly be determined solely by a choice based on alternative incomes (e.g. Hamilton, 2000). Clearly, the non-wage attributes of jobs, like working conditions and general job satisfaction are likely to influence the discounted lifetime utility and hence aspirations to become an entrepreneur. ${ }^{6}$ These types of variables are likely to be empirically important to us, because we are modeling on-the-job search for entrepreneurial opportunities.

In an important new study contributing to this strand of the literature, Lazear (2003, 2004) directs our attention to a certain specific kind of experience by arguing that people with more varied experience are more likely to become entrepreneurs. This jack-of-all-trades view of entrepreneurship adds variation in an employee's experience to the list of factors impacting the probability of becoming an entrepreneur. The key prediction of his model is that individuals with more balanced skills are more likely than others to choose an entrepreneurial career. The primary reason for this is that establishing and running a new firm require skills in a variety of fields, such as human resource management (to hire high-quality employees), technology (to develop or understand the firm's product/service), marketing (to create a market for the product) and finance (to raise initial capital for the firm). If this jack-of-all-trades view is empirically relevant, it could also show up in our aspirations data.

(2001) finds that human capital and psychological factors influence the transitions. In Johansson's (2000) study, the focus is on the effects of financial variables on the transitions.

${ }^{5}$ Other kind of labour market experience may also matter. Gompers, Lerner and Scharfstein (2003) argue in their recent paper that entrepreneurial learning and network building that naturally happen in certain kind of established firms are important for the creation of new firms. Their analysis of venture capital -backed US firms support this Fairchild view of entrepreneurship and not the Xerox view, according to which employees are pushed from large bureaucratic firms into entrepreneurship because of the reluctance of such firms to develop innovative entrepreneurial ideas further. Hellmann (2002) also emphasizes the employees of established companies as a source of new entrepreneurs and shows theoretically that the unavailability of outside resources, such as venture capital, may inactivate these would-be entrepreneurs. Shane and Khurana (2003) test the hypothesis that prior firm-founding and firm-financing experiences affect the willingness to found new firms.

${ }^{6}$ In a recent paper, Poutvaara and Tuomala (2003) estimate earnings functions for workers and entrepreneurs in Finland using an extensive panel of 350,000 individuals over 12 years. Consistent with the idea that non-wage attributes matter, they find that when compared to workers, entrepreneurship involves higher income risks. The finding is interesting from another perspective as well, because it is in line with what Uusitalo (2001) finds: according to his results, less riskaverse workers are more likely to become entrepreneurs. 


\subsection{Determinants of aspirations to switch job}

Like the literature on entrepreneurship, the literature on job search and the dynamics of job change is both plentiful and growing (see e.g. Mortensen, 1986, and Farber, 1999).

From theoretical point of view, wages and tenure are probably the two most natural candidate determinants of job search. Many on-the-job search models imply a negative relation from wage to separations (search), because the higher the current wage of an employee, the less likely that the next (randomly arriving) wage offer is lucrative for the employee (Burdett, 1978, and Jovanovic, 1979a). The negative relation arises also in matching models, because workers are more likely to stay in jobs (matches) with high productivity and wages than in jobs with low productivity and wages (Jovanovic, 1979b).

These models also typically imply that the probability that an individual switches a job decreases with tenure. The theory of on-the-job search suggests that the longer the tenure, the longer the implicit search process that has not led to a switch, and thus the less likely that the current job is not among the best available. The negative relation can also be thought to arise either because of worker heterogeneity (i.e., because of workers prone to search for a new job doing it early) or because of accumulation of employer-specific capital (Farber, 1999).

The foregoing suggests that we should control for tenure, wage and workers' propensity to switch job (i.e., heterogeneity). These variables are however by no means the only variables that affect job search. Empirical studies suggest for example that various other worker characteristics, such as age and socioeconomic status, have significant effects on job search (see for example Blau, 1992, and Pissarides and Wadsworth, 1994, Manning, 2003) and should therefore be controlled, too. Moreover, job satisfaction and various non-pecuniary attributes of the current job influence quits (e.g. Clark, 2001) and should therefore also be related to job search.

Does Lazear's jack-of-all-trades hypothesis have a counterpart in the context of on-the-job search? Maybe, because labour market opportunities available to the jacks-of-all-trades might, for example, be richer than to others. Individuals currently on the job that master a number of different skills and have a balanced set of talents may for example receive job offers simply more frequently. 
Or alternatively, the offers to them may be drawn from a distribution either with a higher mean or higher variance, which both increase the returns to search (for a given reservation wage). A reason for this might for example be that many managerial positions call for a balanced set of talents. The basic intuition underlying this argument is thus not too different from the standard view that education enhances labour market opportunities. We might therefore want allow for the additional possibility that for a given level of education, the people with varied experience search for a new job more frequently than others. The widely studied "hobo syndrome", i.e., that some people may simply have a preference to often switch to a new kind of job, further motivates the inclusion of varied experience as a control variable in the job search equation (see e.g., Munasinghe and Sigman 2004).

\section{Data and empirical specification}

\subsection{Data sources}

The data set that we are using is the Quality of Work Life Survey (QWLS) of Statistics Finland. It is conducted at irregular intervals, the latest being from 1997, which is the year we use. The initial sample for QWLS is derived from a monthly Labour Force Survey (LFS) of Statistics Finland, where a random sample of working age population is selected to a telephone interview. The 1997 QWLS was based on LFS respondents in September and October who were 15-64 old wage and salary earners with normal weekly working time at least five hours. 3795 individuals were selected to the QWLS sample and invited to participate in a faceto-face interview. Out of this sample 2978 persons, or 79 percent, participated (see Lehto and Sutela, 1999).

QWLS includes questions on the personal characteristics and work experience of the respondents, and a large set of questions on perceived working conditions. Statistics Finland supplements QWLS with information from the LFS on e.g. working time and exact labour market status. Supplementary information on the industry and location of the employer, and on the level and field of education of the respondents is from various registers maintained by Statistics Finland. 


\subsection{Definition of variables}

\section{Dependent variables}

The dependent variables used in this study are on-the-job search for entrepreneurial opportunities and on-the-job search for a better job. Unfortunately, the earlier literature has not been able to identify an ideal measure especially for the former type of behaviour. Absent the ideal measures, we have chosen to proxy them as follows: As for entrepreneurial aspirations on-the-job, QWLS includes a question "Have you ever thought about starting your own business or becoming self-employed?", with possible answers "no", “occasionally", “often", and "don't know". We use a binary indicator for the answer "often" as our primary dummy indicator for on-the-job search for entrepreneurial opportunities. We denote this first main dependent variable ENTREPOFTEN. As for search for a better job, there is a question "Have you been looking for another job in the last 6 months?". The responses to this question are used to construct a binary indicator for on-thejob search for a better job. We denote this second main dependent variable of ours JOBSEARCH. We present the exact definitions of these and all the other variables, as well as descriptive statistics, in an Appendix.

Although our measures for the two types of labour market behaviour are certainly imperfect, we have several reasons to trust in them. First, they reflect the same type of search in progress as the variables used to capture on-the-job-search in the previous labour market analyses (see, for example, Blau, 1992 and Pissarides and Wadsworth, 1994) and analyses of latent entrepreneurship (Blanchflower, Oswald and Stutzer, 2001). Second, we can establish the robustness of our results with respect to alternative measures: When studying their robustness, we use a binary indicator for thinking about becoming an entrepreneur at least sometimes, which includes the categories "occasionally" and "often". We denote this variable ENTREPTHINK. We also use all three categories, "no", "occasionally", and "often" as variable ENTREP in an ordered probit analysis. As for job search, we try a binary indicator on whether the respondent has looked for a job during the last four weeks as an alternative to JOBSEARCH. We denote this indicator SEARCH4. Clearly, this variable is a more restricted measure of job switch aspirations. Third, if our measures completely failed to capture the two types of labour market behaviour, we should probably find no meaningful effects. Last but not least, our main measures have the merit of simplicity. 


\section{Regressors}

We consider two sets of control variables (models 1 and 2) that we include sequentially into our empirical specification. In the first model we include several personal and job characteristics. In the second model we add firm and plant characteristics.

The basic personal characteristics include age (age group dummies AGE1 to AGE3), gender (FEMALE dummy), education (education levels EDU1 to EDU4), fields of education (technical EDUTECH, business EDUBUS, health care, teaching etc. EDUHUMCARE), family (MARRIED dummy, CHILDREN for number of children), as well as indicators for the type of the current employment relationship (PARTTIME, TEMPORARY).

MANAGER is an indicator for managerial tasks in current job, OVERTIME indicates that the persons very often works unpaid overtime, and FRESH indicates that the persons can experiment with new things in the current job. We also include SIDEENTREP, which indicates that the individual is presently gaining experience as entrepreneur or farmer in a second job. These controls may explain why an individual is looking for a new job: Managerial position in current job may enhance the likelihood of receiving a job offer (e.g., a call from headhunter), a person working unpaid overtime or (not) being able to experiment with new things in the current job may have a strong incentive scan for a new job, and an individual presently gaining experience as entrepreneur or farmer in a second job may be have a high probability of obtaining job offers. Interestingly, these variables also reflect the kind of characteristics in an individual's current job that are useful if the person starts her own business (see also Gompers, Lerner, and Scharfstein, 2003).

We include in the model the log of monthly pay (LOGWAGE) and years of firm-specific experience (TENURE). We acknowledge that these may be endogenous. If the firm uses wage as a means of lowering the quit rates, turnover and wage should be simultaneously determined. On the other hand, if employees with high propensity of changing jobs leave early, quit intentions and tenure are jointly determined. For the time being we use these two variables without instrumenting them. The relationship between tenure and quit intentions (either to entrepreneurship or another job) may be negative because of employee 
heterogeneity even when there is no true negative state dependence in turnover. We can control the heterogeneity by including a variable that measures the number of job changes in the last five years, SWITCHES. Employees who have switched jobs often in the past, are likely to do it also in the future. We also include a measure for varied experience. To that end, we construct an indicator that equals one if the employee has held more than three clearly different occupations (professions) during her working life. The indicator, which we denote OVER3PROFS, equals zero otherwise. ${ }^{7}$

Finally, we include some job satisfaction dummy variables, i.e., general dissatisfaction with current work, UNSATISFIED; dissatisfaction with superior, BOSSNOSAT; and the opinion that the contents of work are definitely the most important in work, compared to pay, CONTENT; and an indicator on whether the person is a labour union member (UNION).

In the second model we also include characteristics of the firm for which the interviewed employees are working. These include indicators for public or foreign ownership (PUBLIC, FOREIGN), plant size (size groups PSIZE1 to PSIZE4), and industry (industry dummies IND_i, $\mathrm{i}=1, \ldots 12$ ).

\section{$4 \quad$ Results}

\subsection{Univariate analysis}

We present first some descriptive evidence on entrepreneurial and job search intentions. In Table 1 we cross-tabulate ENTREPOFTEN and JOBSEARCH. The figures show that almost $80 \%$ of the respondents are neither looking for a job nor thinking (often) about entrepreneurship. Almost 13\% are searching for a new job, but not interested in becoming an entrepreneur, and 5\% can be classified as latent entrepreneurs that are not actively engaged in on-the-job search for a new job. Less than $3 \%$ of the employed are both potential entrepreneurs and job switchers. Thus, only few are engaged in both search processes.

\footnotetext{
${ }^{7}$ The measure is similar (but not identical) to what Lazear $(2003,2004)$ and Wagner (2003) use to test the jack-of-all-trades hypothesis. It is also should capture the "hobo syndrome", which has been proposed to explain certain individual's job mobility (see Munasinghe and Sigman 2004, and the references therein).
} 
Table 1 suggests that entrepreneurial aspirations on-the-job are not rare, as almost every tenth employee ( $8 \%$ of the employed) has thought often about starting her own business. Entrepreneurial aspirations seem to be less common than aspirations to switch job (15\% of the employed). This difference is, however, driven by the definition of the variables. Had we used ENTREPTHINK, the mean would be much higher ( $37 \%$ of the employed). Because of this ambiguity and the difference in the way the questions are asked, we cannot probably say much about which of the two types of aspirations on-the-job is more common. The table also shows that the two processes are not independent. The dependence is confirmed by a Pearson's chi-square test, which rejects the hypothesis that entrepreneurial aspirations and job search are independent at the 1\% level. This unconditional result is of course driven to a large extent by the large number of non-searchers.

\section{[INSERT TABLE 1 ABOUT HERE]}

\subsection{Basic regression results}

Table 2 reports the results of our basic regressions. We report marginal effects from maximum likelihood estimation of probit models for ENTREOFTEN and JOBSEARCH. The marginal effects are evaluated at the means of the variables and measure the impacts of infinitesimal changes in the continuous variables and discrete changes in the dummy variables. The standard errors are based on the robust Huber-White variance-covariance estimator.

Table 2 shows that despite their apparent similarity, the two search processes are not alike. First, it is more difficult to empirically explain entrepreneurial aspirations than aspirations to switch job. Pseudo- $\mathrm{R}^{2}$ is clearly higher for the latter. Cramer's (1999) $\lambda$-statistic, which is a measure of fit for binary models, suggests the same: The values for the entrepreneurial aspirations and job search models are 0.069 and 0.194 , respectively. So does the percentage correctly predicted, when the sample proportion of the dependent variable is used as the cut-off point (see Cramer 1999). In this case the share of correctly predicted ENTREPOFTEN is 63.0 percent and the corresponding figure for JOBSEARCH is 72.1 percent. Second, the determinants seem to differ. In the models we consider, the only variables that are systematically related to the both search processes are OVER3PROFS, TENURE, and UNSATISFIED. Varied experience, 
as measured by OVER3PROFS, has a positive and statistically significant coefficient in all the models. Job tenure, in turn, is negatively related to both entrepreneurial aspirations and to aspirations to switch job. Job dissatisfaction has a significant positive effect on both search activities.

\section{[INSERT TABLE 2 ABOUT HERE]}

\section{[INSERT TABLE 3 ABOUT HERE]}

Are there any other variables besides these three variables that have consistently a significant relation both to ENTREPOFTEN and to JOBSEARCH? The answer is clear-cut: No. ${ }^{8}$ The model for ENTREPOFTEN suggests that females and married employees are less interested in entrepreneurship; that second job as entrepreneurs has a big impact on the probability of thinking about becoming full time entrepreneur ${ }^{9}$; that the opportunity to experiment with new things in current work and working unpaid overtime have relatively large marginal effects on ENTREPOFTEN; and finally, dissatisfaction with one's superior and considering content most important in work have a significant positive effect on entrepreneurial aspirations. A completely different set of variables is related to JOBSEARCH. The age group dummies are significant, implying that the oldest employees (control group) engage less in on-the-job search. The employment relationship also clearly affects job search, as both part time work and temporary contract dummies get highly significant coefficients. Interestingly, the number of job switches in the past obtains a significant coefficient in the job search equation. This can be interpreted to indicate that there is indeed heterogeneity in the employees' inclination to leave their job.

As to the remaining control variables, their effects on ENTREPOFTEN and on JOBSEARCH are less systematic and not exceedingly robust. Years of education, for example, have no systematic impact on either dependent variable. Similarly, field of education is significant only in the models for entrepreneurship, where employees with technical or natural science education think about

\footnotetext{
${ }^{8}$ Wald-tests for the added controls in model 2 also support this view. In the models for ENTEPOFTEN, the $p$-value of the joint test is 0.05 in model 2. The statistical significance is different in the model for JOBSEARCH, as there the corresponding $p$-value is 0.44 .

${ }^{9}$ The impact is big, because this kind of experience increases the probability of entrepreneurial aspirations by over 30 percent.
} 
entrepreneurship less often. Even this effect disappears once the industry for which the employees are working for is controlled for. Wage is not significant in either equation (but it is weakly significant in the job search model if job satisfaction variables are dropped). Plant size and ownership variables are insignificant in both equations. Lastly, some miscellaneous industry effects can be found (not reported in the table). ${ }^{10}$

To formally test whether the determinants of the two processes differ as a whole we re-estimate the entrepreneurial aspirations and job search models from columns 3 and 4 of Table 2 as a bivariate probit model (not reported in the Table). A Wald-test for the bivariate model indicates, unsurprisingly, that the coefficients of the entire control vectors are not identical in the two probit equations $\left(\chi^{2}(41)\right.$ statistic is 191.59 , with a $p$-value $<0.001$ ). A test of the equality of the coefficients of OVER3PROFS shows, however, that the coefficients are not significantly different from each other $\left(\chi^{2}(1)\right.$ statistic is 0.20 with $p$-value 0.66$)$, but a test of the coefficients of TENURE shows that they are significantly different $\left(\chi^{2}(1)\right.$ statistic is 8.29 with $p$-value 0.04 ). So are the coefficients of UNSATISFIED, for which $\chi^{2}(1)$ statistic is 18.21 ( $p$-value $\left.<0.001\right)$.

The bivariate Probit confirms yet another earlier finding of ours, as it shows that the two search processes are related even after conditioning on the observables. The correlation coefficient of the error terms of the two probit models is 0.277 with a standard error of 0.052 . This result implies that even after controlling for observable characteristics, the conditional independence of the two processes can be rejected at the $1 \%$ significance level. It is useful to remember, however, that unobservable heterogeneity common to many non-searchers drives this result, as there are only few who are both potential entrepreneurs and job switchers.

\footnotetext{
${ }^{10}$ Thinking about becoming an entrepreneur is more common in agriculture and forestry, hotels and restaurants, and public administration. As for job search, it is more common in business services, public administration, and health and social services. This finding is interesting, because we are already controlling for TEMPORARY and PARTTIME. If these controls do their job, the industry effects should not be related to the large share of temporary employment relationships in these public sector fields.
} 


\subsection{Discussion}

In the following, we first briefly discuss the interpretation of the estimated effects of OVER3PROFS, TENURE and UNSATISFIED on the two search processes. We then explore and try to rule out a number of alternative explanations for our empirical findings.

\section{Interpretation}

The statistically significant relation between OVER3PROFS and entrepreneurial aspirations is consistent with Lazear's $(2003,2004)$ jack-of-all-trades hypothesis of entrepreneurship. According to the hypothesis, varied experience matters, because entrepreneurs need to master a number of different skills and have more balanced talents than "specialists". The statistically significant relation between OVER3PROFS and job search suggests, however, that the hypothesis need not be unique to the entrepreneurship, as the jacks-of-all-trades also search on-the-job for a new job more frequently than others.

An issue in interpreting the effect of OVER3PROFS is the variable's potential endogeneity, since the same unobserved effects that influence job search and entrepreneurial intentions may also have an impact on occupational switches. The possibility can be examined using the test suggested by Rivers and Vuong (1988). This test amounts to regressing the possibly endogenous variable on a set of exogenous variables that include the exogenous variables in the model and additional instruments. The residuals from these regressions were then inserted in the original models. A test of the significance of the coefficient is an endogeneity test.

To implement the test, we need to consider the determinants of OVER3PROFS. Finding good instruments is, however, known to be difficult and our study is no exception in this respect. Since OVER3PROFS refers to past labor market experiences, we cannot use as instruments such variables that relate to the present employment. The instruments with which we ended up working are as follows. First, we have the exogenous variables that are included in Model 1 that do not related to the present job, i.e. age, education, field of education, sex, marital status, children, and past job switches. Second, as additional instruments we include unemployment months during the past five years (UMONTHS), an indicator for long-term illness (ILLNESS), and regional dummies. Unemployment 
and illness can be regarded as exogenous shocks that may force the individuals to change occupation. On the other hand, the regional indicators can control for differences in labor market opportunities that may explain occupational switches. These variables turn out not to be direct determinants of ENTREPOFTEN: if included directly in the models for entrepreneurial intentions, they are never significant.

Performing the endogeneity test showed that in the probit models for ENTREPOFTEN the coefficient of the residual is not significant in any of the models. In the probit estimations for JOBSEARCH the coefficient of the residual is not significant, either. Despite these findings, we cannot reliably rule out that these estimated effects reflect some (other) un-modeled forces, such as the hobo syndrome.

Following the above procedure, we also test for the endogeneity of TENURE. In addition to the instruments used for OVER3PROFS, we also used the exogenous variables in model 2 that are related to current job. ${ }^{11}$ Besides these exogenous variables we use as instruments for TENURE also an indicator for high socioeconomic position (SOSECHIGH); dummies for different pay systems (fixed pay, FIXEDPAY; piece rate or commission pay, PIECERATE; or combination of them, FIXANDBONUS). The results of the test indicate that the tenure variable is not endogenous. If the effect of TENURE is indeed exogenous and, in addition, SWITCH and the other controls capture heterogeneity in an employee's propensity to leave their jobs, we can interpret the tenure effect as state dependence. It would speak for accumulation of employer-specific capital. However, we cannot be conclusive on this matter, as our reduced form approach cannot reliably identify the drivers of the relation and as we have only crosssection data.

We also test for the endogeneity of UNSATISFIED, since the same unobservables that affect intentions to leave the present workplace may also correlate with job satisfaction. Using the same instruments as in the case of TENURE, but adding also some working conditions variables (HARM, HAZARD), we obtain the results that UNSATISFIED is not endogenous in the equation for JOBSEARCH, but it is endogenous for ENTREPOFTEN. To see

\footnotetext{
11 These include OVERTIME, FRESH, PARTTIME, TEMPORARY, BOSSNOSAT,
} CONTENTMOST, UNION, PSIZE1-PSIZE4, PUBLIC, FOREIGN, and industry dummies. 
how much this matters, we estimate a bivariate probit model for ENTREPOFTEN and UNSATISFIED, with the latter explained by the instruments used in the endogeneity test. The system is recursive, since entrepreneurial intentions have no impact on satisfaction, but job satisfaction can influence search for entrepreneurship. Further, the explanatory variables are partly different. This makes it possible to ignore the simultaneity in the likelihood and estimate the model as bivariate probit (Greene, 2002). However, this does not change the significance of any of the coefficients that are significant in the ordinary probit model for ENTREPOFTEN. We can therefore conclude that endogeneity is not a serious problem in our case. ${ }^{12}$

Due to the nonlinearity of the probit model, the marginal effects are a function of all the independent variables. This implies that the effects of TENURE and OVER3PROFS on the probabilities of entrepreneurial aspirations and on-thejob search are associated. The effects are associated although the model does not include an explicit interaction term (see for example Ai and Norton, 2003). We show this association in Figure 1, where the (predicted) probabilities are plotted against tenure separately for OVER3PROFS $=1$ and OVER3PROFS $=0 . \mathrm{We}$ evaluate the probabilities at the means of all the other variables and using the parameter estimates of model 2 . The figure shows that the probabilities fall with tenure, but the fall is much steeper in the case of job search. Tenure dampens the effect of varied experience, as the probabilities of entrepreneurial aspirations of those with and those without varied experience approach each other as tenure increases. The gap between the two probabilities of job switch aspirations narrows even faster.

\section{[INSERT FIGURE 1 ABOUT HERE]}

We show in Figure 2 the effects of TENURE and UNSATISFIED on the probabilities. In this case, being unsatisfied leads to a much higher probability of job search than being satisfied with current job. This effect falls with tenure, but even at 40 years of tenure, the probability of job search is still higher for the

\footnotetext{
${ }^{12}$ We also tested for the endogeneity of LOGWAGE, since wage may be used as a means to restrict quits, but found no evidence for it. The instruments were the same as in the test of endogeneity of TENURE.
} 
dissatisfied. In the case of entrepreneurial aspirations the difference in probabilities in the two groups is clearly smaller.

\section{[INSERT FIGURE 2 ABOUT HERE]}

\section{Robustness tests}

We have performed a number of robustness tests. We do not report these tests in detail to save space, as we run several new regressions both for on-the-job search for entrepreneurial opportunities and for on-the-job search for a better job. Anticipating the outcome of these tests, each of them illustrates that the two processes are rather different and, in particular, that they confirm our earlier result that the only variables that are systematically related to the both search processes are OVER3PROFS, TENURE, and UNSATISFIED.

Robustness test 1: Is a mis-specified distributional assumption driving our findings? To address this question, we re-run our basic models as linear probability models, which may be more robust to the underlying assumptions about the model specification than the probit model (see for example Wooldridge 2002). The coefficients of OVER3PROFS, TENURE, and UNSATISFIED were again significant in all the models for ENTREPOFTEN and JOBSEARCH. Moreover, the coefficients of these variables were fairly close to the marginal effects that we obtained from the probit estimations. This is natural, since most of our explanatory variables are dichotomous.

Robustness test 2: Are mis-measured dependent variables driving our findings? To address this question, we re-run our basic regressions using alternative measures for the two dependent variables. Instead of ENTREPOFTEN we try ENTREPTHINK. We also use ordered probit to explain ENTREP that has three ordered categories. The results of this robustness test echo our previous findings. OVER3PROFS, TENURE, and UNSATISFIED are related to entrepreneurial aspirations in the same way as in the other models. There are, however, some differences in the other coefficients. In ordered probit estimation for ENREP and probit estimation for ENTREPTHINK the variables CHILDREN, MANAGER and LOGWAGE obtain significant positive coefficients and UNION a significant negative coefficient. Further, MARRIED, and BOSSNOSAT are no longer significant. Finally, instead of JOBSEARCH we explain SEARCH4. In 
this case TENURE and UNSATISFIED are still significant, but OVER3PROFS, while still positive, is not. This may reflect the fact that since SEARCH4 is based on the last four weeks, it is a less reliable measure of on-the-job search. Among the other variables, BOSSNOSAT obtains now a significant positive coefficient, whereas the age group dummies and SWITCHES are no longer significant. ${ }^{13}$

\section{Conclusions}

The purpose of this paper is to contribute to the existing empirical analyses of labour market behavior of employed individuals by exploring the previously overlooked possibility that the individuals on-the-job may have entrepreneurial aspirations in addition to aspirations to switch job.

To study the two processes side-by-side, we use Finnish data on the entrepreneurial and job search aspirations of a random sample of individuals currently on-the-job. We report three main findings:

- Neither entrepreneurial aspirations nor aspirations to switch job are uncommon, but only few of the employed are engaged in both search processes. Almost every tenth employee has thought often about starting her own business.

- Despite their apparent similarity, the two search processes are not alike: It is more difficult to empirically explain entrepreneurial aspirations than aspirations to switch job. Further, it turns out that out of the observable characteristics of the employed, only varied experience, job tenure, and job dissatisfaction are associated both with entrepreneurial aspirations and aspirations to switch job. Varied experience and job dissatisfaction are

\footnotetext{
${ }^{13}$ In addition to these robustness tests we also tried controlling the total work experience of the survey respondents by adding the dummy variables for experience categories, EXP1-EXP4. This kind of work experience is of course correlated with AGE, and TENURE, but as we are not interested in the age effects per se, the correlation is not a source of concern to us. Controlling for the total work experience does not affect the conclusions on our main variable of interest. Capital constraints are yet another prominent omitted variable. Not having perfect controls for capital constraints should not, however, be of great concern to us for two reasons. First, capital constraints have apparently had only a minor effect on transitions from salaried employment to selfemployment in Finland in the 1990s (Uusitalo 2001). Johansson's (2000) probit estimations echo this view, as he finds that the quantitative impact of a wealth variable on the transitions is not very large. Second, our regressions include both LOGWAGE and age group dummies that control for the effects of financial capital to some extent. Including these controls is important, because they are also important determinants of home ownership and because Johansson (2000) has found that home ownership is positively associated with the probability of becoming self-employed.
} 
directly related to the probability of having entrepreneurial aspirations and aspirations to switch job, while job tenure is inversely related to them. No other observable characteristic of the employed is robustly related to both processes.

- After controlling for a number of observable characteristics of the employed, the conditional independence of the two processes can be rejected at the $1 \%$ significance level. Unobservable heterogeneity common to many non-searchers drives this result, as there are only few who are both potential entrepreneurs and job switchers.

$* * * * * * * * * * * * * * * * * * * * * * * *$

\section{References}

Ai, Chunrong and Norton, Edward C., 2003, Interaction terms in logit and probit models, Economics Letters, Vol. 80, pp. 123-129.

Audretsch, David B., 2003, Entrepreneurship: A Survey of the Literature, European Commission, Enterprise Directorate-General, Enterprise Papers No. 14.

Blanchflower, David G., 2000, Self-employment in OECD countries, Labour Economics, Vol. 7, pp. 471-505.

Blanchflower, David G., and Oswald, Andrew J., 1998, What Makes an Entrepreneur?, Journal of Labor Economics, Vol. 16, pp. 26-52.

Blanchflower, David G., Oswald, Andrew, and Stutzer, Alois, 2001, Latent entrepreneurship across nations, European Economic Review, Vol. 45, pp. 680-691.

Blau, David, 1992, An empirical analysis of employed and unemployed job search behavior, Industrial and Labor Relations Review, Vol. 45, pp. 738-752.

Burdett, Kenneth, 1978, A theory of employee job search and quit rates, American Economic Review, Vol. 68, pp. 212-220.

Clark, Adrew E., 2001, What really matters in a job? Hedonic measurement using quit data, Labour Economics, Vol. 8, pp. 223-242.

Cramer, J. S., 1999, Predictive performance of the binary logit model in unbalanced samples, The Statistician, Vol. 48, pp. 85-94.

Dunn, Thomas and Holtz-Eakin, Douglas, 2000, Financial capital, human capital and the transition to self-employment: Evidence from intergenerational links, Journal of Labor Economics, Vol. 18, pp. 282-305.

Evans, David S. and Jovanovic, Boyan, 1989, An estimated model of entrepreneurial choice under liquidity constraints, Journal of Political Economy, Vol. 97, pp. 808-827.

Farber, Henry S., 1999, Mobility and stability: the dynamics of job change in labor markets, in Orley Ashenfelter and David Card, eds., Handbook of Labor Economics, Vol. 3B, 2439-2483. 
Gompers, Paul, Lerner, Josh, and Scharfstein, David, 2003, Entrepreneurial spawning: Public corporations and the genesis of new ventures, 1986-1999, NBER Working Paper, No. 9819.

Greene, William H., 2003, Econometric Analysis, $5^{\text {th }}$ ed., Upper Saddle River: Pearson Education.

Hamilton, Barton H., 2000, Does entrepreneurship pay? An empirical analysis of returns to self-employment, Journal of Political Economy, Vol. 108, pp. 604-632.

Hellmann, Thomas, 2002, When do employees become entrepreneurs? Stanford Graduate School of Business Research Paper, No. 1770.

Holtz-Eakin, Douglas, Joulfaian, David, and Rosen, Harvey S., 1994, Sticking it out: Entrepreneurial survival and liquidity constraints, Journal of Political Economy, Vol. 102, pp. 53-75.

Johansson, Edvard, 2000, Self-employment and liquidity constraints: Evidence from Finland, Scandinavian Journal of Economics, Vol. 102, pp. 123-134.

Jovanovic, Boyan, 1979a, Job matching and the theory of turnover, Journal of Political Economy, Vol. 87, pp. 972-990.

Jovanovic, Boyan, 1979b, Firm-specific capital and turnover, Journal of Political Economy, Vol. 87, pp. 1246-1260.

Krueger, Norris F. Jr., Reilly, Michael D., and Carsrud, Alan L., 2000, Competing models of entrepreneurial intentions, Journal of Business Venturing, Vol. 15, pp. 411-432.

Lazear, Edward P., 2002, Entrepreneurship, NBER Working Paper, No. 9109.

Lazear, Edward P., 2004, Balanced skills and entrepreneurship, American Economic Review, Papers and Proceedings, Vol. 94, pp. 208-211.

Le, Anh T., 1999, Empirical studies of self-employment, Journal of Economic Surveys, Vol. 13, pp. 381-415.

Lehto, Anna-Maija and Sutela, Hanna, 1999, Efficient, More Efficient, Exhausted. Findings of Finnish Quality of Work Life Surveys 1977 - 1997, Helsinki: Statistics Finland.

Manning, Alan, 2003, Monopsony in Motion, Princeton: Princeton University Press.

Mortensen, Dale T., 1986, Job search and labor market analysis, in Orley Ashenfelter and Richard Layard, eds. Handbook of Labor Economics, Vol. 2, pp. 849-919.

Munasinghe, Lalith and Sigman, Karl, 2004, A hobo syndrome? Mobility, wages, and job turnover, Labour Economics, Vol. 11, pp. 191-218.

Parker, Simon C., 2004, The Economics of Self-Employment and Entrepreneurship, Cambridge: Cambridge University Press.

Pissarides, Christopher A. and Wadsworth, Jonathan, 1994, On-the-job search: Some empirical evidence from Britain, European Economic Review, Vol. 38, pp. 385-401.

Pissarides, Christopher A., 1984, Search unemployment with on-the-job search, Review of Economic Studies, Vol. 61, pp. 457-476.

Poutvaara, Panu and Tuomala, Juha, 2003, Entrepreneurs and workers, Centre for Economic and Business Research, Discussion Paper 2003-14. 
Rivers, Douglas and Vuong, Quang H., 1988, Limited information estimators and endogeneity tests for simultaneous probit models, Journal of Econometrics, Vol. 39, pp. 347-366.

Shane, Scott and Khurana, Rakesh, 2003, Bringing individuals back in: the effects of career experience on new firm founding, Industrial and Corporate Change, Vol. 12, pp. 519-543.

Uusitalo, Roope, 2001, Homo entreprenaurus?, Applied Economics, Vol. 33, pp. 1631-1638.

Wagner, Joachim, 2003, Testing Lazear's jack-of-all-trades view of entrepreneurship with German micro data, Applied Economics Letters, Vol. 10, pp. 687-689.

Wooldridge, Jeffrey M., 2002, Econometric Analysis of Cross Section and Panel Data, Cambridge, Mass.: MIT Press. 
Table 1: Cross tabulation of entrepreneurial aspirations with job search

\begin{tabular}{|c|c|c|c|}
\hline \multirow[t]{2}{*}{ ENTREPOFTEN } & \multicolumn{2}{|c|}{ JOBSEARCH } & \multirow[t]{2}{*}{ Total } \\
\hline & 0 & 1 & \\
\hline 0 & $\begin{array}{l}2366 \\
(0.936)\end{array}$ & $\begin{array}{l}375 \\
(0.831)\end{array}$ & $\begin{array}{l}2741 \\
(0920)\end{array}$ \\
\hline 1 & $\begin{array}{l}161 \\
(0.064)\end{array}$ & $\begin{array}{l}76 \\
(0.169)\end{array}$ & $\begin{array}{l}237 \\
(0.080)\end{array}$ \\
\hline Total & 2527 & 451 & 2978 \\
\hline $\begin{array}{l}\text { Pearson } \chi^{2}(1) \\
\text { p-value }\end{array}$ & & & $\begin{array}{l}57.384 \\
0.000\end{array}$ \\
\hline
\end{tabular}

Note: shares of column total in parentheses. 
Table 2: Probit marginal effects

\begin{tabular}{|c|c|c|c|c|}
\hline & $\begin{array}{l}\text { (Model 1) } \\
\text { ENTREPOFTEN }\end{array}$ & $\begin{array}{l}\text { (Model 1) } \\
\text { JOBSEARCH }\end{array}$ & $\begin{array}{l}\text { (Model 2) } \\
\text { ENTREPOFTEN }\end{array}$ & $\begin{array}{l}\text { (Model 2) } \\
\text { JOBSEARCH }\end{array}$ \\
\hline AGE1 & $\begin{array}{l}-0.016 \\
(0.017)\end{array}$ & $\begin{array}{l}0.092 \\
(0.034) * * *\end{array}$ & $\begin{array}{l}-0.015 \\
(0.018)\end{array}$ & $\begin{array}{l}0.098 \\
(0.036) * * *\end{array}$ \\
\hline AGE2 & $\begin{array}{l}-0.009 \\
(0.011)\end{array}$ & $\begin{array}{l}0.060 \\
(0.014)^{* * *}\end{array}$ & $\begin{array}{l}-0.011 \\
(0.012)\end{array}$ & $\begin{array}{l}0.063 \\
(0.015)^{* * *}\end{array}$ \\
\hline EDU1 & $\begin{array}{l}-0.000 \\
(0.024)\end{array}$ & $\begin{array}{l}-0.032 \\
(0.025)\end{array}$ & $\begin{array}{l}0.016 \\
(0.029)\end{array}$ & $\begin{array}{l}-0.029 \\
(0.027)\end{array}$ \\
\hline EDU2 & $\begin{array}{l}0.016 \\
(0.019)\end{array}$ & $\begin{array}{l}-0.018 \\
(0.023)\end{array}$ & $\begin{array}{l}0.025 \\
(0.020)\end{array}$ & $\begin{array}{l}-0.018 \\
(0.024)\end{array}$ \\
\hline EDU3 & $\begin{array}{l}0.005 \\
(0.022)\end{array}$ & $\begin{array}{l}0.031 \\
(0.028)\end{array}$ & $\begin{array}{l}0.011 \\
(0.023)\end{array}$ & $\begin{array}{l}0.031 \\
(0.029)\end{array}$ \\
\hline EDUHUMCARE & $\begin{array}{l}-0.016 \\
(0.015)\end{array}$ & $\begin{array}{l}0.028 \\
(0.023)\end{array}$ & $\begin{array}{l}0.004 \\
(0.020)\end{array}$ & $\begin{array}{l}0.019 \\
(0.024)\end{array}$ \\
\hline EDUBUS & $\begin{array}{l}-0.010 \\
(0.015)\end{array}$ & $\begin{array}{l}0.027 \\
(0.021)\end{array}$ & $\begin{array}{l}-0.005 \\
(0.015)\end{array}$ & $\begin{array}{l}0.028 \\
(0.022)\end{array}$ \\
\hline EDUTECH & $\begin{array}{l}-0.025 \\
(0.013)^{* *}\end{array}$ & $\begin{array}{l}0.007 \\
(0.019)\end{array}$ & $\begin{array}{l}-0.014 \\
(0.014)\end{array}$ & $\begin{array}{l}0.013 \\
(0.020)\end{array}$ \\
\hline FEMALE & $\begin{array}{l}-0.036 \\
(0.011)^{* * *}\end{array}$ & $\begin{array}{l}-0.012 \\
(0.013)\end{array}$ & $\begin{array}{l}-0.031 \\
(0.011)^{* * *}\end{array}$ & $\begin{array}{l}-0.015 \\
(0.014)\end{array}$ \\
\hline MARRIED & $\begin{array}{l}-0.026 \\
(0.012) * *\end{array}$ & $\begin{array}{l}-0.012 \\
(0.014)\end{array}$ & $\begin{array}{l}-0.026 \\
(0.012)^{* *}\end{array}$ & $\begin{array}{l}-0.011 \\
(0.014)\end{array}$ \\
\hline CHILDREN & $\begin{array}{l}0.005 \\
(0.003)\end{array}$ & $\begin{array}{l}0.000 \\
(0.004)\end{array}$ & $\begin{array}{l}0.002 \\
(0.003)\end{array}$ & $\begin{array}{l}-0.002 \\
(0.004)\end{array}$ \\
\hline PARTTIME & $\begin{array}{l}0.011 \\
(0.019)\end{array}$ & $\begin{array}{l}0.055 \\
(0.024)^{* *}\end{array}$ & $\begin{array}{l}0.002 \\
(0.019)\end{array}$ & $\begin{array}{l}0.053 \\
(0.024)^{* *}\end{array}$ \\
\hline TEMPORARY & $\begin{array}{l}0.011 \\
(0.014)\end{array}$ & $\begin{array}{l}0.100 \\
(0.020)^{* * *}\end{array}$ & $\begin{array}{l}0.014 \\
(0.015)\end{array}$ & $\begin{array}{l}0.102 \\
(0.022)^{* * *}\end{array}$ \\
\hline MANAGER & $\begin{array}{l}0.011 \\
(0.011)\end{array}$ & $\begin{array}{l}0.008 \\
(0.013)\end{array}$ & $\begin{array}{l}0.012 \\
(0.011)\end{array}$ & $\begin{array}{l}0.004 \\
(0.014)\end{array}$ \\
\hline FRESH & $\begin{array}{l}0.052 \\
(0.018)^{* * *}\end{array}$ & $\begin{array}{l}0.003 \\
(0.017)\end{array}$ & $\begin{array}{l}0.053 \\
(0.018)^{* * *}\end{array}$ & $\begin{array}{l}0.002 \\
(0.017)\end{array}$ \\
\hline SIDEENTFARM & $\begin{array}{l}0.340 \\
(0.086)^{* * *}\end{array}$ & $\begin{array}{l}0.106 \\
(0.081)\end{array}$ & $\begin{array}{l}0.341 \\
(0.087) * * *\end{array}$ & $\begin{array}{l}0.104 \\
(0.081)\end{array}$ \\
\hline OVERTIME & $\begin{array}{l}0.041 \\
(0.024)^{*}\end{array}$ & $\begin{array}{l}-0.010 \\
(0.022)\end{array}$ & $\begin{array}{l}0.031 \\
(0.022)\end{array}$ & $\begin{array}{l}-0.014 \\
(0.022)\end{array}$ \\
\hline SWITCHES & $\begin{array}{l}0.003 \\
(0.002)\end{array}$ & $\begin{array}{l}0.012 \\
(0.003)^{* * *}\end{array}$ & $\begin{array}{l}0.003 \\
(0.002)\end{array}$ & $\begin{array}{l}0.012 \\
(0.004)^{* * *}\end{array}$ \\
\hline OVER3PROFS & $\begin{array}{l}0.030 \\
(0.016)^{*}\end{array}$ & $\begin{array}{l}0.035 \\
(0.018)^{*}\end{array}$ & $\begin{array}{l}0.038 \\
(0.016)^{* *}\end{array}$ & $\begin{array}{l}0.041 \\
(0.019)^{* *}\end{array}$ \\
\hline TENURE & $\begin{array}{l}-0.002 \\
(0.001)^{* *}\end{array}$ & $\begin{array}{l}-0.006 \\
(0.001)^{* * *}\end{array}$ & $\begin{array}{l}-0.001 \\
(0.001)^{* *}\end{array}$ & $\begin{array}{l}-0.006 \\
(0.001)^{* * *}\end{array}$ \\
\hline LOGWAGE & $\begin{array}{l}0.017 \\
(0.016)\end{array}$ & $\begin{array}{l}-0.019 \\
(0.018)\end{array}$ & $\begin{array}{l}0.023 \\
(0.016)\end{array}$ & $\begin{array}{l}-0.012 \\
(0.019)\end{array}$ \\
\hline BOSSNOSAT & $\begin{array}{l}0.065 \\
(0.035)^{*}\end{array}$ & $\begin{array}{l}0.040 \\
(0.036)\end{array}$ & $\begin{array}{l}0.069 \\
(0.036)^{*}\end{array}$ & $\begin{array}{l}0.051 \\
(0.038)\end{array}$ \\
\hline UNSATISFIED & $\begin{array}{l}0.050 \\
(0.025)^{* *}\end{array}$ & $\begin{array}{l}0.286 \\
(0.039)^{* * *}\end{array}$ & $\begin{array}{l}0.048 \\
(0.025)^{*}\end{array}$ & $\begin{array}{l}0.285 \\
(0.040) * * *\end{array}$ \\
\hline CONTENTMOST & $\begin{array}{l}0.029 \\
(0.016)^{*}\end{array}$ & $\begin{array}{l}-0.022 \\
(0.015)\end{array}$ & $\begin{array}{l}0.030 \\
(0.016)^{*}\end{array}$ & $\begin{array}{l}-0.025 \\
(0.015)^{*}\end{array}$ \\
\hline
\end{tabular}




\begin{tabular}{l|llll} 
UNION & -0.027 & -0.000 & -0.016 & -0.001 \\
& $(0.013)^{* *}$ & $(0.014)$ & $(0.013)$ & $(0.015)$ \\
PSIZE1 & & 0.014 & -0.009 \\
& & $(0.022)$ & $(0.024)$ \\
PSIZE2 & & 0.003 & -0.010 \\
PSIZE3 & & $(0.020)$ & $(0.023)$ \\
& & -0.007 & -0.012 \\
PUBLIC & & $(0.018)$ & $(0.023)$ \\
& & -0.016 & -0.019 \\
FOREIGN & & $(0.016)$ & $(0.019)$ \\
& & & 0.008 & -0.008 \\
\hline Pseudo R & & & $(0.018)$ & $(0.022)$ \\
Observations & 0.081 & & 0.095 & 0.208 \\
\hline
\end{tabular}

Note: Robust standard errors in parentheses. * significant at 10\%; ** significant at $5 \%$; *** significant at 1\% level. AGE3, EDU4, EDUOTHER, and PSIZE4 are used as reference groups 
Figure 1: Probabilities of entrepreneurial aspirations and job search as functions of tenure and varied experience

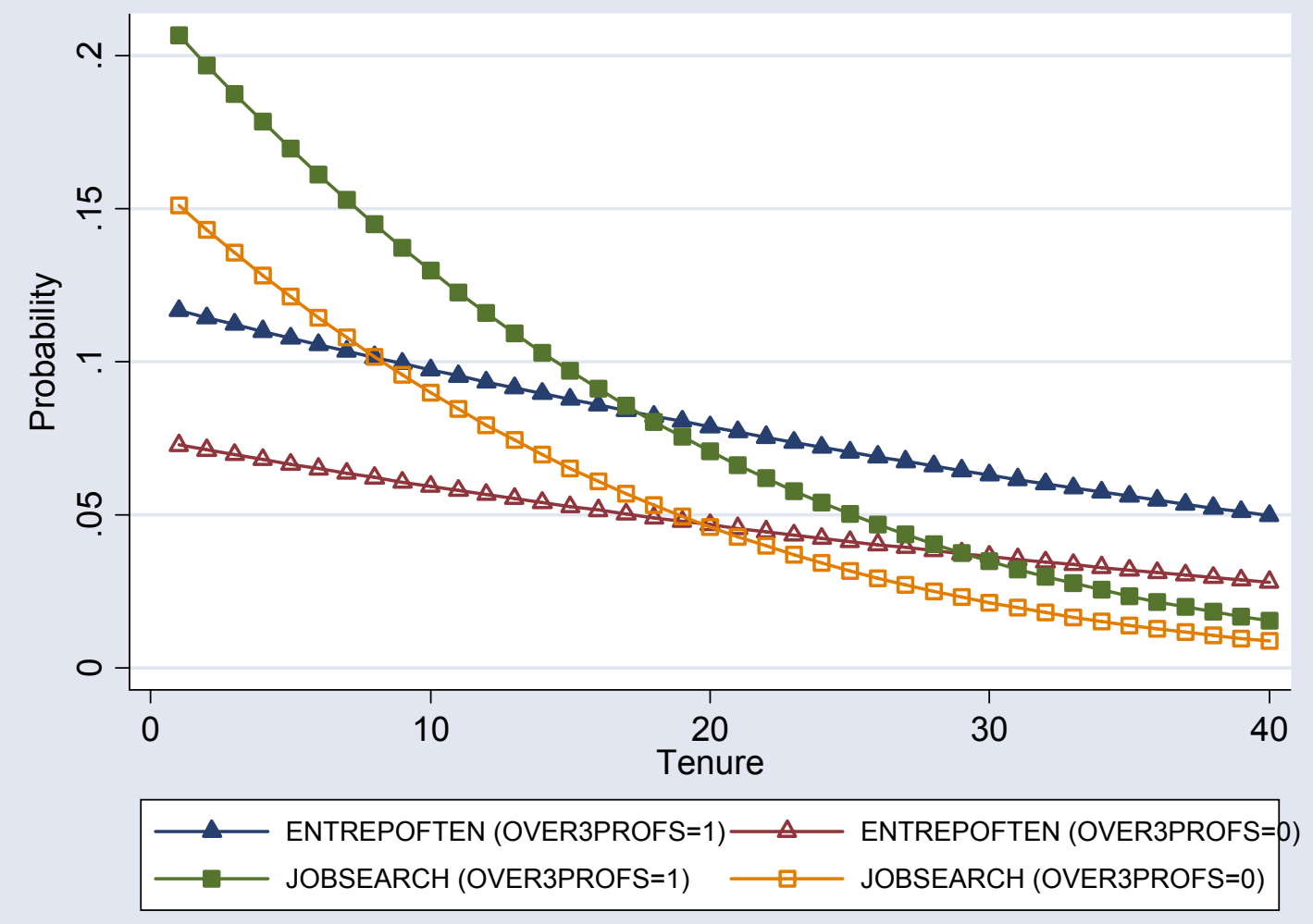

Figure 2: Probabilities of entrepreneurial aspirations and job search as functions of tenure and job dissatisfaction

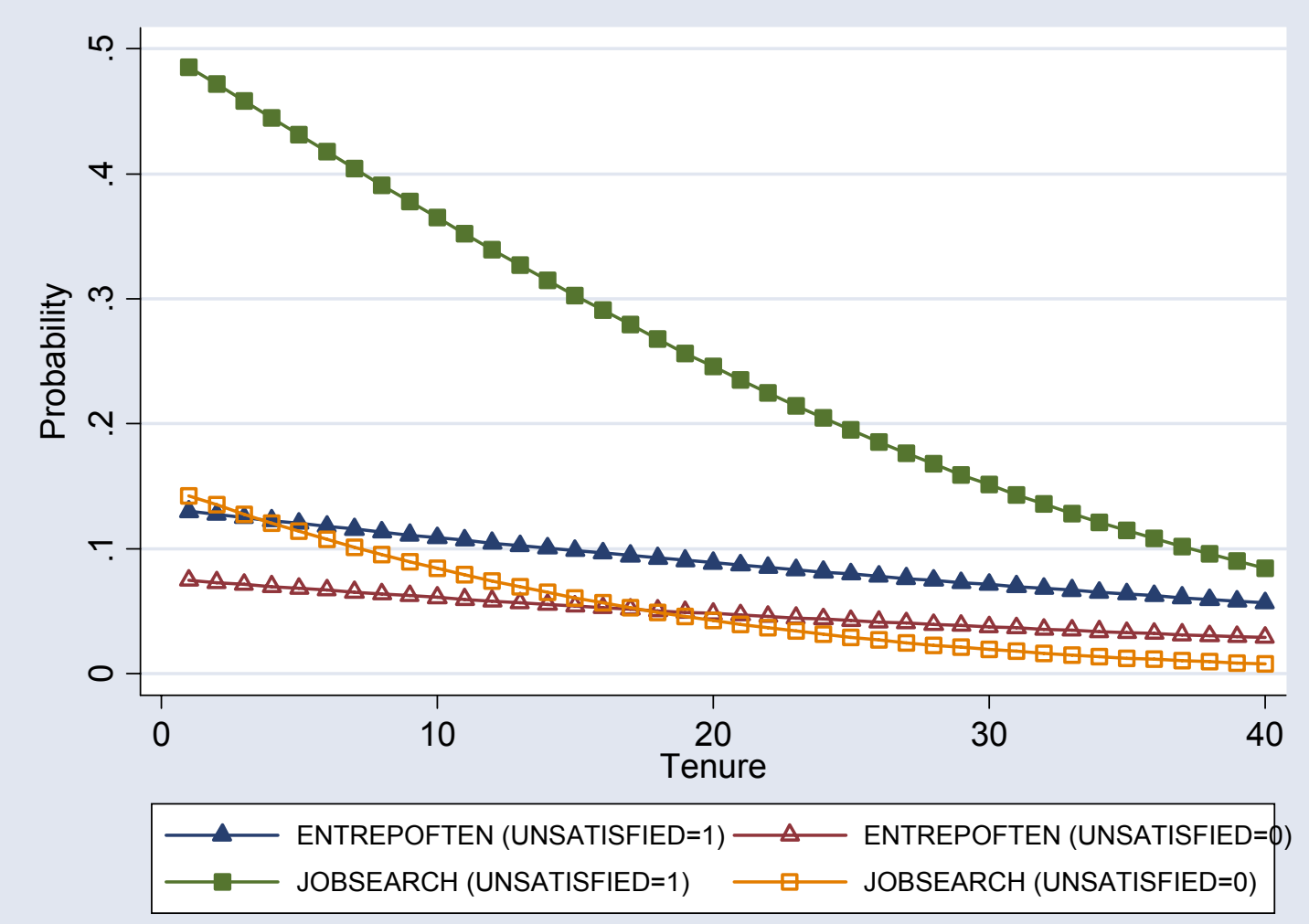




\section{Data Appendix}

In this appendix we report the definitions of our variables in detail and present descriptive statistics.

Entrepreneurship and job search variables

ENTREPOFTEN $=1$ if has thought about starting own business or becoming self-employed "often", = 0 if "occasionally", "not", don't know" or missing answer.

ENTREPTHINK $=1$ if has about of entrepreneurship or self-employment "often" or "occasionally", $=0$ if "not", don't know" or missing.

ENTREP $=1$ if has not thought of entrepreneurship, $=2$ if occasionally, $=3$ if often. Don't know and missing are excluded.

JOBSEARCH $=1$ if has been looking for another job in the last 6 months (while in present job), $=0$ if not or missing answer.

SEARCH4 $=1$ if has looked for a job in the last 4 weeks, $=0$ if not or missing.

\section{Work experience and employment relationship variables}

MANAGER $=1$ if tasks involve supervision of others or delegation of tasks to other employees, $=0$ otherwise

SIDEENTREP $\quad=1$ if has second job as farmer of entrepreneur, $=0$ otherwise

OVERTIME $=1$ if does almost daily overtime for which receives no compensation, $=0$ otherwise

FRESH $=1$ if experiments with new things in work continuously or very frequently, $=0$ otherwise

\section{SWITCHES number of job changes in last 5 years}

OVER3PROFS $\quad=1$ if has been in over three distinctly different kinds of occupations during his/her life, $=0$ otherwise

UMONTHS unemployment months in last 5 years

TENURE = years in current workplace in continuous employment relationship

EXP1 $=1$ if total work experience under 3 years, $=0$ otherwise

EXP2 $=1$ if total work experience is $3-12$ years, $=0$ otherwise

EXP3 $=1$ if total work experience is $13-27$ years, $=0$ otherwise

EXP4 $=1$ if total work experience is over 27 years, $=0$ otherwise

PARTTIME $=1$ if works part time, $=0$ otherwise

TEMPORARY $=1$ if currently fixed-term employment relationship, $=0$ otherwise

HARM $\quad=1$ if at least one adverse factor that affects work 'very much' (out of 20 different kind of factors) $=0$ otherwise

HAZARD $=1$ if at least one factor experienced as a 'distinct hazard' (out of 13 different kind of factors), $=0$ otherwise 
Personal characteristics variables

\begin{tabular}{|c|c|}
\hline AGE1 & $=1$ if age $15-24,=0$ otherwise \\
\hline AGE2 & $=1$ if age $25-44,=0$ otherwise \\
\hline AGE3 & $=1$ if age $45-64,=0$ otherwise \\
\hline FEMALE & $=1$ if female, $=0$ if male \\
\hline MARRIED & $=1$ if married or cohabiting, $=0$ otherwise \\
\hline CHILDREN & number of children under 18 years living at home \\
\hline EDU1 & $=1$ if comprehensive education, $=0$ otherwise \\
\hline EDU2 & $=1$ if upper secondary or vocational education, $=0$ otherwise \\
\hline EDU3 & $=1$ if polytechnic or lower university degree, $=0$ otherwise \\
\hline EDU4 & $=1$ if higher university degree, $=0$ otherwise \\
\hline EDUTECH & $\begin{array}{l}=1 \text { if education in technology, natural science or computer science, }=0 \\
\text { otherwise }\end{array}$ \\
\hline EDUBUS & $=1$, if education in business, law or social sciences, $=0$ otherwise \\
\hline EDUHUMCARE & $=1$ if education in health care, teaching, or humanities, $=0$ otherwise \\
\hline EDUOTHER & $\begin{array}{l}=1 \text { if education in agriculture and forestry or unspecified field, }=0 \text { otherwise } \\
\text { (reference group) }\end{array}$ \\
\hline SOSECHIGH & $\begin{array}{c}=1 \text { if social economic position high (higher white collar employee, } \\
\text { management position etc.), }=0 \text { otherwise }\end{array}$ \\
\hline UNION & $=1$ if member of labour union, $=0$ otherwise \\
\hline ILLNESS & $=1$ if suffers from any medically diagnosed chronic illness, $=0$ otherwise \\
\hline
\end{tabular}

$\underline{\text { Work attitude variables }}$

SATISFIED $\quad=1$ if "very satisfied" with current job, $=0$ otherwise

BOSSNOSAT $=1$ if very dissatisfied with superior's leadership, $=0$ otherwise

CONTENT $\quad=1$ if contents are definitely the most important in work, $=0$ otherwise (pay definitely the most important, pay slightly more important than contents, contents slightly more important than pay)

Income variables

LOGWAGE $\quad=\ln ($ MIDWAGE), where MIDWAGE is the mid point of monthly income category. Categories are under FIM 3000, then increases by 1000 from 3000 to 16000 , by 2000 from 18000 to 2000 , by 5000 from 20000 to 30000 , and the final category is over 30000. For the last and first category, MIDWAGE is the category limit. Income is gross income, including shift work and bonuses, but excluding overtime pay.

FIXEDPAY $\quad=1$ if fixed monthly or hourly pay (including shift work supplement), $=0$ otherwise

PIECERATE $\quad=1$ if only piece-work or commission pay, $=0$ otherwise

FIXEDANDBONUS $=1$ if pay consists of fixed basic pay plus piece work bonus, productivity bonus or commission, $=0$ otherwise 
Firm characteristics variables

PUBLIC = current employer is state or municipality, $=0$ otherwise

FOREIGN = current employer is private, mainly foreign-owned enterprise, $=0$ otherwise

PSIZE1 $=1$ if number of persons working in same establishment is under $10,=0$ otherwise

PSIZE2 $=1$ if number of persons working in same establishment is $10-49,=0$ otherwise

PSIZE3 $=1$ if number of persons working in same establishment is $50-499,=0$ otherwise

PSIZE4

$=1$ if number of persons working in same establishment is 500 or more, $=0$ otherwise

IND i

dummies for industries $\mathrm{i}=\mathrm{AB}$ (agriculture, forestry, fishing), CDE (mining, manufacturing, energy), F (construction), G (trade), $\mathrm{H}$ (hotels and restaurants), I (transportation and communications), J (finance), K (real estate and business services, L (public administration), M (education), $\mathrm{N}$ (health and social services), OPX (other public and private services, households, industry unknown)

dummies for $\mathrm{i}=1, \ldots, 21$ NUTS3 regions 
Table A1: Descriptive statistics

\begin{tabular}{|c|c|c|c|c|c|}
\hline Variable & Obs & Mean & Std. Dev. & Min & Max \\
\hline ENTREPOFTEN & 2978 & 0.080 & 0.271 & 0 & 1 \\
\hline ENTREPTHINK & 2978 & 0.372 & 0.483 & 0 & 1 \\
\hline ENTREP & 2971 & 1.453 & 0.638 & 1 & 3 \\
\hline JOBSEARCH & 2978 & 0.151 & 0.359 & 0 & 1 \\
\hline SEARCH4 & 2978 & 0.064 & 0.244 & 0 & 1 \\
\hline MANAGER & 2978 & 0.317 & 0.466 & 0 & 1 \\
\hline SIDEENTREP & 2978 & 0.011 & 0.103 & 0 & 1 \\
\hline OVERTIME & 2978 & 0.061 & 0.239 & 0 & 1 \\
\hline FRESH & 2978 & 0.117 & 0.321 & 0 & 1 \\
\hline SWITCHES & 2975 & 0.742 & 1.645 & 0 & 30 \\
\hline OVER3PROFS & 2978 & 0.130 & 0.336 & 0 & 1 \\
\hline UMONTHS & 2968 & 3.931 & 8.857 & 0 & 60 \\
\hline TENURE & 2970 & 9.558 & 9.317 & 0 & 47 \\
\hline EXP1 & 2968 & 0.055 & 0.227 & 0 & 1 \\
\hline EXP2 & 2968 & 0.259 & 0.438 & 0 & 1 \\
\hline EXP3 & 2968 & 0.434 & 0.496 & 0 & 1 \\
\hline EXP4 & 2968 & 0.253 & 0.435 & 0 & 1 \\
\hline PARTTIME & 2974 & 0.102 & 0.303 & 0 & 1 \\
\hline TEMPORARY & 2978 & 0.180 & 0.385 & 0 & 1 \\
\hline HARM & 2978 & 0.287 & 0.452 & 0 & 1 \\
\hline HAZARD & 2978 & 0.338 & 0.473 & 0 & 1 \\
\hline AGE1 & 2978 & 0.084 & 0.278 & 0 & 1 \\
\hline AGE2 & 2978 & 0.554 & 0.497 & 0 & 1 \\
\hline AGE3 & 2978 & 0.361 & 0.480 & 0 & 1 \\
\hline FEMALE & 2978 & 0.531 & 0.499 & 0 & 1 \\
\hline MARRIED & 2978 & 0.735 & 0.442 & 0 & 1 \\
\hline CHILDREN & 2978 & 0.856 & 1.362 & 0 & 18 \\
\hline EDU1 & 2978 & 0.238 & 0.426 & 0 & 1 \\
\hline EDU2 & 2978 & 0.560 & 0.496 & 0 & 1 \\
\hline EDU3 & 2978 & 0.115 & 0.319 & 0 & 1 \\
\hline EDU4 & 2978 & 0.087 & 0.282 & 0 & 1 \\
\hline EDUHUMCARE & 2978 & 0.163 & 0.369 & 0 & 1 \\
\hline EDUBUS & 2978 & 0.165 & 0.371 & 0 & 1 \\
\hline EDUTECH & 2978 & 0.269 & 0.444 & 0 & 1 \\
\hline EDUOTHER & 2978 & 0.404 & 0.491 & 0 & 1 \\
\hline SOSECHIGH & 2973 & 0.242 & 0.428 & 0 & 1 \\
\hline UNION & 2978 & 0.791 & 0.407 & 0 & 1 \\
\hline ILLNESS & 2975 & 0.254 & 0.435 & 0 & 1 \\
\hline SATISFIED & 2978 & 0.306 & 0.461 & 0 & 1 \\
\hline BOSSNOSAT & 2978 & 0.035 & 0.183 & 0 & 1 \\
\hline CONTENT & 2978 & 0.137 & 0.344 & 0 & 1 \\
\hline LOGWAGE & 2947 & 9.096 & 0.426 & 8.006 & 10.309 \\
\hline FIXEDPAY & 2978 & 0.838 & 0.368 & 0 & 1 \\
\hline PIECERATE & 2978 & 0.025 & 0.157 & 0 & 1 \\
\hline FIXANDBONUS & 2978 & 0.119 & 0.324 & 0 & 1 \\
\hline PUBLIC & 2968 & 0.343 & 0.475 & 0 & 1 \\
\hline FOREIGN & 2927 & 0.071 & 0.258 & 0 & 1 \\
\hline PSIZE1 & 2951 & 0.276 & 0.447 & 0 & 1 \\
\hline
\end{tabular}




\begin{tabular}{|c|c|c|c|c|c|}
\hline PSIZE2 & 2951 & 0.363 & 0.481 & 0 & 1 \\
\hline PSIZE3 & 2951 & 0.280 & 0.449 & 0 & 1 \\
\hline PSIZE4 & 2951 & 0.081 & 0.273 & 0 & 1 \\
\hline IND_AB & 2978 & 0.014 & 0.119 & 0 & 1 \\
\hline IND_CDE & 2978 & 0.233 & 0.423 & 0 & 1 \\
\hline IND_F & 2978 & 0.058 & 0.235 & 0 & 1 \\
\hline IND_G & 2978 & 0.105 & 0.306 & 0 & 1 \\
\hline IND_H & 2978 & 0.028 & 0.166 & 0 & 1 \\
\hline IND_I & 2978 & 0.084 & 0.277 & 0 & 1 \\
\hline IND_J & 2978 & 0.026 & 0.158 & 0 & 1 \\
\hline IND_K & 2978 & 0.082 & 0.274 & 0 & 1 \\
\hline IND_L & 2978 & 0.063 & 0.243 & 0 & 1 \\
\hline IND_M & 2978 & 0.091 & 0.288 & 0 & 1 \\
\hline IND_N & 2978 & 0.166 & 0.372 & 0 & 1 \\
\hline IND_OPX & 2978 & 0.050 & 0.219 & 0 & 1 \\
\hline REG1 & 2978 & 0.267 & 0.442 & 0 & 1 \\
\hline REG2 & 2978 & 0.096 & 0.295 & 0 & 1 \\
\hline REG3 & 2978 & 0.048 & 0.214 & 0 & 1 \\
\hline REG4 & 2978 & 0.035 & 0.184 & 0 & 1 \\
\hline REG5 & 2978 & 0.090 & 0.286 & 0 & 1 \\
\hline REG6 & 2978 & 0.034 & 0.181 & 0 & 1 \\
\hline REG7 & 2978 & 0.033 & 0.179 & 0 & 1 \\
\hline REG8 & 2978 & 0.025 & 0.157 & 0 & 1 \\
\hline REG9 & 2978 & 0.029 & 0.167 & 0 & 1 \\
\hline REG10 & 2978 & 0.046 & 0.210 & 0 & 1 \\
\hline REG11 & 2978 & 0.032 & 0.177 & 0 & 1 \\
\hline REG12 & 2978 & 0.049 & 0.217 & 0 & 1 \\
\hline REG13 & 2978 & 0.033 & 0.178 & 0 & 1 \\
\hline REG14 & 2978 & 0.027 & 0.162 & 0 & 1 \\
\hline REG15 & 2978 & 0.012 & 0.111 & 0 & 1 \\
\hline REG16 & 2978 & 0.063 & 0.243 & 0 & 1 \\
\hline REG17 & 2978 & 0.017 & 0.129 & 0 & 1 \\
\hline REG18 & 2978 & 0.033 & 0.178 & 0 & 1 \\
\hline REG19 & 2978 & 0.017 & 0.129 & 0 & 1 \\
\hline REG20 & 2978 & 0.014 & 0.117 & 0 & 1 \\
\hline
\end{tabular}

